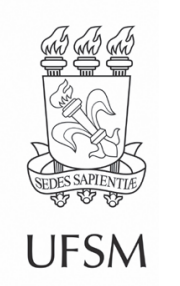

\title{
Artigos
}

\section{Amazon plinthosols: carbon stocks and physical properties under different land uses}

\author{
Estoques de carbono e propriedades físicas de plintossolos em \\ diferentes usos do solo na Amazônia
}

\section{Alexis de Sousa Bastos ${ }^{\oplus}{ }^{\oplus}$, Carlos Roberto Sanquetta" ${ }^{\oplus}$, Vanderlei Maniesi"l ${ }^{\bullet}$, Mateus Niroh Inoue Sanquetta" ${ }^{\prime}$, Ana Paula Dalla Corte" ${ }^{\prime \prime}$}

\author{
'Centro de Estudos Rioterra, Porto Velho, RO, Brazil \\ "Universidade Federal do Paraná, Curitiba, PR, Brazil \\ '"Universidade Federal de Rondônia, Porto Velho, RO, Brazil
}

\begin{abstract}
The population growth and the climate changes impose challenges to society, especially regarding food supply and the maintenance of desirable soil conditions. Besides, it is necessary to reduce greenhouse gas emissions. Hence, there is a necessity of studies addressing the understanding of soil conditions under different land uses, as soils can become carbon pools or sources depending on management practices. This study was conducted in soil profiles of Amazon Plinthosols under different land uses: undisturbed forests, cattle ranching pastures, and mixed crops. Soil density and carbon fraction were assessed at four depths $(0-5,5-10,10-20$, and 20-40 cm), while particle size and mineralogy were examined at 0-20 and 20-40 cm. Soils under undisturbed forests presented lower densities and higher carbon fractions when compared to other land uses. These soils also presented the highest carbon stock; however, the Tukey test indicated no significant differences. Soil densities were lower in forest environments. Cattle ranching pastures presented higher carbon stocks when compared to mixed crops (at age 10 years). Our results indicated that proper soil management practices are needed to maintain the soil productive capacity after converting forested areas for other uses. Plinthosols, due to its textural and mineralogical characteristics, presented high amounts of quartz, demonstrating how sensitive these environments are to changes in the landscape due to deforestation and how unstable the maintenance of carbon stocks is because of such conditions. This study provides useful information to the understanding of the carbon stock in Amazon Plinthosols. It may be helpful to improve the Brazilian Inventory of Anthropogenic Emissions and Removals of Greenhouse Gases and to understand the impacts of land-use change.
\end{abstract}

Keywords: Land-use change; Soil density; Carbon fraction; Carbon stock 


\section{RESUMO}

O crescimento populacional e as questões climáticas impõem desafios à sociedade, principalmente no que diz respeito ao abastecimento de alimentos e à manutenção de condições desejáveis do solo. Além disso, há uma evidente necessidade de reduzir as emissões de gases de efeito estufa, notadamente àquelas causadas por mudanças no uso do solo. Portanto, há necessidade de estudos que abordem o entendimento das condições do solo sob os diferentes usos do solo, uma vez que esses podem se tornar fontes de carbono dependendo das práticas de manejo. Este estudo foi conduzido em perfis de Plintossolos Amazônicos sob: florestas primárias, pastagens para pecuária e plantios mistos de restauração florestal. A densidade e o teor de carbono foram avaliados em quatro profundidades (0$5,5-10,10-20$ e 20-40 cm), enquanto as propriedades físicas foram examinadas nas profundidades de 0-20 e 20-40 cm. Solos sob florestas primárias apresentaram as menores densidades e os maiores teores de carbono quando comparados a outros usos da terra. Esses solos também apresentaram o maior estoque de carbono. Entretanto, não foi observada diferença significativa pelo teste de Tukey para ambas variáveis. As pastagens apresentaram maiores estoques de carbono quando comparados aos plantios mistos (aos 10 anos). Nossos resultados indicaram que práticas de manejo adequadas são necessárias para a manutenção da capacidade produtiva do solo após a conversão de florestas para outros usos. Os Plintossolos, por suas características texturais e mineralógicas, apresentaram elevados teores de quartzo, notadamente nas camadas superficiais, demonstrando quão sensíveis às mudanças na paisagem. O estoque de carbono no solo é, portanto, sensível às mudanças na sua cobertura. Este estudo fornece informações úteis para o entendimento do estoque de carbono em Plintossolos na Amazônia Brasileira, bem como para aprimorar as estimativas realizadas no Inventário Nacional de Emissões de Gases de Efeito Estufa.

Palavras chaves: Mudança no uso do solo; Densidade do solo; Teor de carbono; Estoque de carbono

\section{INTRODUCTION}

The world currently faces two closely related challenges: population growth and climate change (IPCC, 2013). As the population grows, the higher the demand for natural resources availability is (SAATH; FACHINELLO, 2018)..

Soils are the primary resource for food production. Hence, maintaining soil quality is crucial in securing food availability for future generations. However, as the world population grows, soil degradation increases. Thousands of hectares of arable land are lost annually due to inadequate soil management. Moreover, the rise of temperatures, caused by climate changes, promotes growth gaps in several crops (ABRAMOVAY, 2010; MARQUES et al., 2017) and increases greenhouse gas emissions (GHG). Thus, the current soil management practices imply higher amounts of carbon 
emitted to the atmosphere, contributing to a failure in reaching the Intergovernmental Panel on Climate Change (IPCC) goals to maintain the global warming rate below $1.5^{\circ} \mathrm{C}$ until 2100 (ROGELJ et al., 2016).

It is estimated that tropical soils store 2.5 times more carbon than the vegetation (BARROS; FERNANDES, 2016). Despite this, upper layers of soil $(0-20 \mathrm{~cm})$, the ones more susceptible to land preparation, account for the most significant carbon stock part. Indeed, agricultural uses were responsible for $21 \%$ of anthropogenic GHG emissions in 2010 (TUBIELLO et al., 2015). The maintenance of carbon stocks in soils depends, in particular, on management practices (ARYAL et al., 2018). However, related studies indicated that land-use change to agricultural uses promote significant soil structure changes, generally worsening soil conditions and increasing GHG emission (COSTA et al., 2009; BARROS; FEARNSIDE, 2016).

The Food and Agriculture Organization of the United Nations (FAO) estimates that the global population will reach circa 9.3 billion by 2050 and about $70 \%$ will live in urban areas (FAO, 2013). Thus, to meet the food demand, it is expected that food production increase by $60 \%$. The United Nations (2009) reports that more than 120 million hectares of land will be needed to meet this demand for food.

In this scenario, Latin America and Sub-Saharan Africa emerge as they encompass approximately $90 \%$ of the world's agricultural land (FAO, 2013). Inevitably, tropical forests such as the Brazilian Amazon will face tremendous pressure regarding land-use change issues (BROADBENT et al., 2008). It is estimated that the conversion of forest areas into agricultural uses accounts for $60 \%$ of the world's deforestation (DE JONG et al., 2010). The main drivers of deforestation in the Amazon are illegal logging, cattle farming, and road building (FAO, 2017), and deforested area reached ca. 16\% of the total area, corresponding to circa 55 million ha (INPE, 2018).

However, land-use change in developing countries has been a significant issue. Usually, cattle ranching pastures are severely degraded. There is ca. 200 million ha of degraded pastures in Latin America (GAITÁN et al., 2016). In Brazil, cattle ranching 
pastures encompass ca. 171 million ha (SAATH; FACHINELLO, 2018), and in the southwestern Amazon, 40\% of pastures are degraded.

Plinthosols extends in ca. 60 million ha worldwide, and it is the most common soil in the wet tropics. These soils are common in the Brazilian Amazon basin (GARCIA et al., 2013). Thus, it is crucial to understand carbon cycling and the impact of different land uses in Plinthosols, especially in the Brazilian Amazon. There is, however, a lack of studies addressing this particular question. The proper understanding of Plinthosols is crucial for developing management practices to reduce environmental issues and avoid loss of forested areas.

This study aimed to assess the carbon stock and physical properties of Amazon Plinthosols under different land uses: undisturbed forests, cattle ranching pastures, and mixed crops.

\section{MATERIALS AND METHODS}

Data derived from Plinthosols samples collected in forests, pastures, and mixed crops in Itapuã do Oeste municipality, Rondônia state. Soil samples were collected around the Jamari National Forest (encompassed by the Tropical Amazon rainforest).

The climate zone is Aw (tropical savannah with dry winter) (ALVARES et al., 2013). The mean annual temperature ranges from $24^{\circ} \mathrm{C}$ to $26^{\circ} \mathrm{C}$, and the rainfall varies from 2,400 to $2,600 \mathrm{~mm}$.

\subsection{Soil sampling}

Density, carbon fraction, particle size, and mineralogy were examined in nine soil profiles. Additionally, we assessed the carbon stock in these soil profiles (Figure 1). A total of 36 undisturbed samples were collected from four different depths (05, 5-10, 10-20, and 20-40 cm) to determine density and carbon fraction. Deformed samples assessed particle size and mineralogy from 0-20 and 20-40 cm depth, totaling 18 samples. The sampling was carried out in relatively flat relief environments (COSTA 
et al., 2009), observing their use history. Soil samples from undisturbed forests (UF) were collected inside the Jamari National Forest, while samples from cattle ranching pastures (CRP) and mixed crops (MC) came from small-farm properties that use a family agriculture system.

Figure 1 - Diagram of sampling for soil density, carbon fraction, particle size and mineralogy

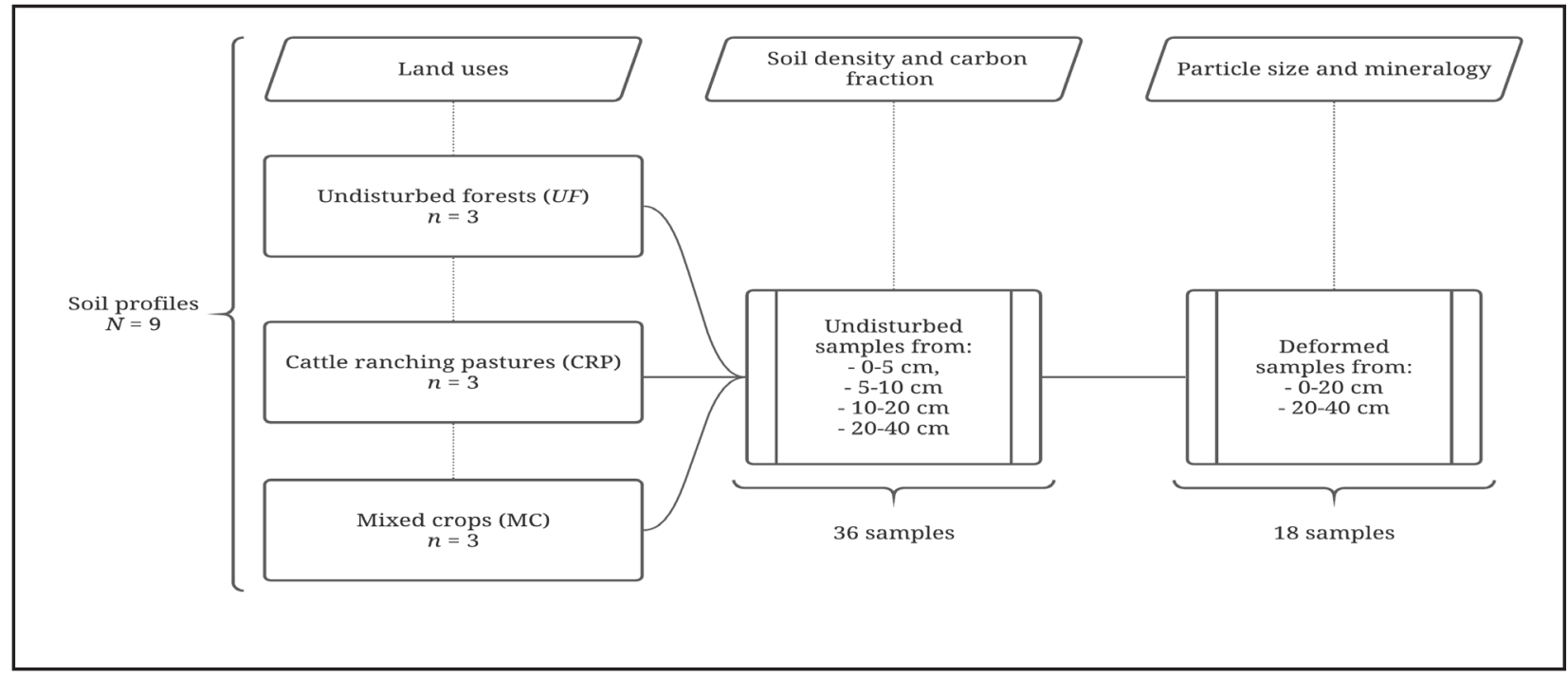

Source: Authors (2020)

Undisturbed forest areas (PF) were selected by performing a spatiotemporal analysis from satellite images and scenes from 1984 to the present day. The soil profiles form cattle ranching pastures (CRP) were established in family farming properties, in which CRP was established for at least ten years with signal grass (Urolchoa brizantha Hochst ex A. Rich R. Webster), synonymy of Brachiaria brizantha. None CRP has ever been limed or fertilized and the management practice is the extensive cattle ranching. Mixed crops (MC) consisted of young stands of forest restoration planted in January 2011. Mixed crops were planted in the vicinity of CRP areas, replacing them as a form of environmental regularization. The planting was conducted using drills for individual cots and spacing of $4 \times 3$ meters. 


\subsection{Soil density and carbon fraction}

The 36 undisturbed soil samples were collected using volumetric rings of 100 $\mathrm{cm}^{3}$. Subsequently, they were oven-dried at $65^{\circ} \mathrm{C}$ until they reached constant weight for mass determination. The soil density was obtained by dividing the mass $(\mathrm{m})$ by the ring volume (v).

A portion of each sample was fractioned and sieved using a Mesh n. 18 (1 mm). The carbon fraction $\left(\mathrm{gC} \mathrm{g}^{-1}\right)$ was determined by the dry combustion method in a Leco C-144 analyzer (MAAS et al., 2020).

The soil carbon stock (MgC.ha-1) was estimated by multiplying the dry matter of each layer by the carbon fraction using the following Equation (1):

$$
\mathrm{SCS}_{i}=\rho_{i}\left(\mathrm{e}_{i} \cdot 10000\right)\left(\mathrm{CF}_{i} / 100\right)
$$

where: $\mathrm{SCS}_{i}=$ soil carbon stock of the soil layer $i(\mathrm{Mg}$ ha-1); $\rho=$ density of the soil layer $i$ $\left(\mathrm{g} \cdot \mathrm{cm}^{-3}\right) ; \mathrm{e}=$ thickness of the soil layer $i(\mathrm{~m}) ; \mathrm{CF}=$ carbon fraction of the soil layer $i\left(\mathrm{gC} \cdot \mathrm{g}^{-1}\right)$.

The results of density, carbon fraction, and carbon stocks were evaluated by performing standard deviation analyses. The Tukey test compared the measurements at a $95 \%$ probability level.

\subsection{Granulometry}

The granulometric analysis was conducted to determine the proportion of each fraction of clay $(<0.002 \mathrm{~mm})$, silt $(0.002-0.5 \mathrm{~mm})$, and sand $(0.05-2.0 \mathrm{~mm})$. A shaker table was used for the sand separation (DOURADO et al., 2012), while the laser diffraction method (CILAS 1064 laser particle size analyzer) for clay and silt fractions.

The 18 deformed soil samples were sieved using standard series of overlapped sieves (opening diameters: 5, 10, 20, 40,60, 100, and 150 meshes). After sieving, each sample was oven-dried to determine the weight of each fraction. 


\subsection{Mineralogy}

The qualitative analyses of minerals and mineral clay were performed using total pressed powder and X-ray diffraction.

The mineral quantification of sand fractions was performed by using a binocular lens. To determine the mineral content in the sand fraction, properties such as color, brightness, cleavage, magnetism, trace, hardness, and transparency were observed by a binocular loupe.

\section{RESULTS AND DISCUSSIONS}

The soil density was always lower in undisturbed forests (UF) when compared to cattle ranching pastures (CRP) and mixed crops (MC). However, the Tukey test indicated no significant differences, regardless of the soil layer (Table 1). CRP and MC presented higher density values, as Bernoux et al. (1998) found in their study. This fact can be explained due to livestock impacts (current activity in CRP) (e.g. COSTA et al., 2009). We also noticed that livestock impact persisted within the soil for at least 11 years after the mixed crop (MC), corroborating with Lenci et al. (2018).

Several studies have confirmed livestock impacts on soil compaction and have shown that animal trampling is a compression vector. Despite the increase in densities after the forest replacement in other environments, soils under CRP had the lowest standard deviation at all depths.

An increased density impacts other soil properties by reducing aeration, water infiltration, and increased soil resistance to root penetration, especially in clayey soils; once such soils are more prone to compaction and restrictive to root growth than sandy soils (DEXTER, 2004; GALLAGE; UCHIMURA, 2010). Consequently, there is a decrease in productivity because, in addition to natural fertility, the productivity depends on a suitable porous system in the layers where the roots develop. Together with the decrease in such spaces, there is less circulation of nutrient solution, greater difficulty of root growth, and less access to nutrients by roots (SHAH et al., 2017). 


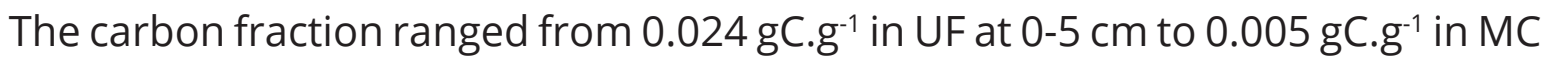
at $20-40 \mathrm{~cm}$. We noticed that the higher the soil depth is, the lower the carbon fraction is, regardless of land use. The Tukey test evidenced this relationship, as the means differed depending on the soil layer (Table 1). These results reinforce the findings from Kato et al. (2010).

Table 1 - Descriptive statistics for soil density, carbon fraction, and carbon stock in Amazon Plinthosols under different land uses

\begin{tabular}{|c|c|c|c|c|}
\hline Soil layer & $0-5 \mathrm{~cm}$ & $5-10 \mathrm{~cm}$ & $10-20 \mathrm{~cm}$ & $20-40 \mathrm{~cm}$ \\
\hline \multicolumn{5}{|c|}{ Soil density $\left(\mathrm{g} \cdot \mathrm{cm}^{-3}\right)$} \\
\hline Undisturbed forests (UF) & $1.125 \pm 0.114(\mathrm{a})$ & $1.229 \pm 0.094(a)$ & $1.284 \pm 0.120(a)$ & $1.196 \pm 0.131(\mathrm{a})$ \\
\hline $\begin{array}{l}\text { Cattle ranching pastures } \\
\text { (CRP) }\end{array}$ & $1.337 \pm 0.039(\mathrm{a})$ & $1.366 \pm 0.076(a)$ & $1.382 \pm 0.038(a)$ & $1.268 \pm 0.051(a)$ \\
\hline Mixed crops (MC) & $1.240 \pm 0.185(\mathrm{a})$ & $1.390 \pm 0.162(\mathrm{a})$ & $1.439 \pm 0.180(a)$ & $1.355 \pm 0.208(a)$ \\
\hline \multicolumn{5}{|c|}{ Carbon fraction $\left(\mathrm{gC.g}^{-1}\right)$} \\
\hline Undisturbed forests (UF) & $0.024 \pm 0.006(a)$ & $0.020 \pm 0.006(a b)$ & $0.016 \pm 0.005(a b)$ & $0.009 \pm 0.001(b)$ \\
\hline $\begin{array}{l}\text { Cattle ranching pastures } \\
\text { (CRP) }\end{array}$ & $0.022 \pm 0.009(a)$ & $0.017 \pm 0.008(a b)$ & $0.013 \pm 0.004(a b)$ & $0.008 \pm 0.001(b)$ \\
\hline Mixed crops (MC) & $0.024 \pm 0.010(a)$ & $0.015 \pm 0.001(a b)$ & $0.009 \pm 0.001(a b)$ & $0.005 \pm 0.000(b)$ \\
\hline \multicolumn{5}{|c|}{ Carbon stock (MgC.ha-1) } \\
\hline Undisturbed forests (UF) & $13.29 \pm 2.09(\mathrm{a})$ & $12.43 \pm 2.76(a)$ & $20.88 \pm 5.12(a)$ & $20.63 \pm 1.17(a)$ \\
\hline $\begin{array}{l}\text { Cattle ranching pastures } \\
\text { (CRP) }\end{array}$ & $14.63 \pm 5.85(a)$ & $11.59 \pm 4.55(a)$ & $18.67 \pm 5.37(a)$ & $21.22 \pm 2.09(a)$ \\
\hline Mixed crops (MC) & $14.34 \pm 4.47(\mathrm{a})$ & $10.07 \pm 1.36(a)$ & $12.36 \pm 1.47(b)$ & $14.78 \pm 2.264(b)$ \\
\hline
\end{tabular}

Source: Authors (2020)

Soils under undisturbed forests (UF) presented the highest carbon fraction, regardless of depth. However, for the $0-5 \mathrm{~cm}$ layer, we noticed a similar value for MC $\left(0.024 \mathrm{gC} . \mathrm{g}^{-1}\right)$ compared to UF $\left(0.024 \mathrm{gC} . \mathrm{g}^{-1}\right)$.This fact can be attributed to litter production, which incorporates nutrients to the soil. The persistency of undisturbed forests suggests a higher accumulation and decomposition of litter, contributing to higher carbon fraction at 5-10 cm (Table 1). Salimon et al. (2007) reported similar values for carbon fraction in forests and cattle ranching pastures in the southwestern Amazon after ten years. 
Table 1 displays the means and standard deviations of carbon stocks for different land uses in Amazon Plinthosols. The soil carbon stock from 0-40 cm ranged from 67.233 MgC.ha-1 (UF) to 51.551 MgC.ha-1 (MC). These values are within 18.5282.31 MgC.ha-1 found for different crops in Petric Plinthosols (e.g., GATTO et al., 2010). The two first soil layers $(0-5$ and $5-10 \mathrm{~cm})$ presented lower carbon stocks for all land uses, and this may be explained because of the lower thickness of these layers.

Although no explicit differences were noticed between UF and CRP, regardless of soil depth, we noticed that MC always showed lower values (Table 1), differing in the last two layers (10-20 and 20-40 cm). Considering the soil thickness of 0-20 cm, UF presented the higher carbon stock (46.60 $\mathrm{MgC.ha}^{-1}$ ), followed by CRP (44.89 MgC.ha-1), and MC (36.77 MgC.ha-1). This layer in forests $(0-20 \mathrm{~cm})$ corresponds to $69.31 \%$ of the 0-40 cm layer total stock.

By comparing the soil carbon stock in UF and CRP, the differences were irrelevant for the layers $0-20$ and $20-40 \mathrm{~cm}: 3.79 \%$ and $1.68 \%$, respectively. However, when comparing these carbon stock values for UF and MC, we noticed that the variations were $26.74 \%$ and $40.19 \%$. The layer $0-20 \mathrm{~cm}$ in CRP and MC represents $67.91 \%$ and $71.33 \%$ of the total stocks in the layer $0-40 \mathrm{~cm}$. Bernoux et al. (2006) verified values for the layer 0-30 cm corresponding to $44 \%$ and $66 \%$ of the total stock up to 1-m depth, demonstrating the importance of the upper horizon of Amazon soils for agricultural purposes. Due to its low natural fertility characteristics, high acidity, and sandy texture, colloids in organic matter of the upper layers are the primary source of nutrition for cultivars.

Therefore, management practices in tropical soils should be emphasized since they are responsible for better structuring and stabilizing soil aggregates. Effective management practices avoid erosion, immobilization, and release of nutrients, offering cation exchange sites and carbon storage sites.

The fast cycling and incorporation of carbon into subsurface horizons by grassroots can explain the variation in carbon volume and the differences between CRP and MC. This fact is not observed with the roots of MC tree species (PULROLNIK, 2009). 
To obtain an approximate idea of emissions from land-use change by converting forest into cattle ranching pastures, Cerri et al. (2007) projected a carbon loss in Amazonian soils of approximately $7 \%$ for the $0-20 \mathrm{~cm}$ layer between 2000 and 2030. Fearnside and Barbosa (1998) carried out a more conservative estimation of carbon emissions stored in soils and reported $5.6 \%$ values at the same layer. Thus, it is equivalent to state that, based on the mean values for this soil area (UF $=46.60$ $\left.\mathrm{MgC}_{\mathrm{h}} \mathrm{a}^{-1}\right)$, Rondônia state, which has six million hectares with pastures, would have contributed to the emission of 15,659,280 MgC.ha-1.

These values may be higher if we consider that this estimate is a simple projection using the data obtained in this work. Plinthosols, although representative, are not common in the Amazon. Latosols and Argisols are common and may contain more expressive clay contents and, consequently, higher carbon stocks. Cerri et al. (1991) studied the impacts of converting forests into pastures on a very clayey Yellow Oxisol, estimated better initial losses after three years (24.31\%) in a forest area converted into pasture.

Despite this difference, MCs areas presented the second-highest average at the layer 0-5 cm: 14.34 MgC.ha-1. The CRP had the highest value (14.63 $\mathrm{MgC.ha}^{-1}$ ), and the UF had the lowest value among the measured systems (13.29 MgC.ha-1) (Table 1). There was an average increase of $10.08 \%$ in CRP areas concerning UF areas at the layer 0-5 cm. However, the MC areas presented the highest gradient variation between the stocks at the layers $0-5$ to $5-10 \mathrm{~cm}$, with a variation of $42.35 \%$, while UF and CRP presented $6.96 \%$ and $26.25 \%$, respectively.

Soils with CRP presented significant values for carbon stocks, but the standard deviations indicate a significant heterogeneity of stocks probably due to different forms of management. This environment presented the highest standard deviation for all the layers between 0 and $20 \mathrm{~cm}$, followed by MC areas at the layer $0-5 \mathrm{~cm}$, and UF at the layers 5-10 and 10-20 cm. For the layer between 20 and $40 \mathrm{~cm}$, MCs highest standard deviation was found, followed by CRP and UF. 
The relationship between increases in densities and layers may explain the higher carbon stocks in soils with pastures. Studies such as Desjardins et al. (2004) have reached similar conclusions regarding the contributions of carbon stocks in pastures in the Amazon.

There is an association between carbon stock and clay proportion. The sample UF3, containing $92.78(0-20 \mathrm{~cm})$ and $89.79 \%(20-40 \mathrm{~cm})$ of clay, presented the highest stock among all samples in this environment, which is up to $53.52 \%$ higher than the point UF2, which had the lowest stock among the sites sampled in the forest. This behavior was also noticed in cattle ranching pastures. The point CRP1 had the highest stock at the 0-40 cm layer: $80.67 \mathrm{MgC.ha}^{-1}$ of carbon. At this site, clay contents reached $69.90 \%$ at 20-40 cm (Table 2). Among all studied environments, at the layer 20-40 cm, the point CRP1 presented the highest individual stock: $23.25 \mathrm{MgC.ha}^{-1}$ of carbon. Inverse results were measured at the point CRP2, which presented the lowest clay concentration. The point CRP2 presented a carbon stock at the layer 0-40 cm: 48.63 MgC.ha ${ }^{-1}$. That is, it is $65.89 \%$ lower than CRP1. By comparing the points, there is a difference of $45.32 \%$ with clay contents.

Table 2 - Particle size distribution at the layers 0-20 and 20-40 cm in Amazon Plinthosols under different land uses

\begin{tabular}{|c|c|c|c|c|c|c|}
\hline \multirow{2}{*}{$\begin{array}{c}\text { Soil layer } \\
\text { Particle size proportion (\%) }\end{array}$} & \multicolumn{3}{|c|}{$0-20 \mathrm{~cm}$} & \multicolumn{3}{|c|}{$20-40 \mathrm{~cm}$} \\
\hline & Sand & Silt + Clay & SE & Sand & Silt + Clay & SE \\
\hline Undisturbed forests (UF) & 28.34 & 71.66 & \pm 18.99 & 22.20 & 77.80 & \pm 10.90 \\
\hline Cattle ranching pastures (CRP) & 47.82 & 52.18 & \pm 14.99 & 38.00 & 62.00 & \pm 12.07 \\
\hline Mixed crops (MC) & 48.56 & 51.44 & \pm 20.53 & 42.60 & 57.40 & \pm 19.94 \\
\hline
\end{tabular}

Source: Authors (2020)

The relations between carbon and clay contents are due to the more remarkable ability of clay to conserve organic matter (TRUMBORE; CAMARGO, 2009). These relations are less prominent in the upper portions of the soil $(0-20 \mathrm{~cm})$ because of the influence of root systems and contributions from litter production. Therefore, even in 
environments where sand values were high concerning silt + clay, there were points with higher levels and carbon stocks, as can be observed, especially in mixed crop sites.

Minerals are dominant in the sand and clay fractions. In the sand fraction, quartz minerals were dominant because of relative enrichment due to their remarkable weathering stability. These results indicate that only the most stable minerals remain in the environment because of the intense weathering (PIRES et al., 2009). The only minerals in clay fractions were gibbsite and kaolinite. Their compositions are rich in aluminum, contributing to an increase in the toxicity and acidity of those soils.

The aluminum content is closely related to the amount of organic matter in the soil. The presence of aluminum ions decreases as the organic matter increases (RONQUIM, 2010), which is another factor to consider regarding acceptable management practices for arable soils in Amazon to decrease the acidity and toxicity caused by aluminum.

Table 3 displays the mineralogy pattern for Plinthsols profiles under different land uses. Although all soil profiles presented elevated concentrations of quartz (from 83.33 to $98.66 \%$ at $0-20 \mathrm{~cm}$, and from 72.00 to $98.00 \%$ at $20-40 \mathrm{~cm}$ ), soil profiles under UF presented the lowest values (0-20 cm: 88.11\%; $20-40 \mathrm{~cm}: 80.55 \%)$. Cattle ranching pastures and mixed crops presented mean values ranging from $93.33 \%$ (CRP at 20-40 $\mathrm{cm}$ ) to $95.67 \%$ (MC at $0-20 \mathrm{~cm}$ ).

Table 3 - Soil mineralogy in sand fraction of Amazon Plinthosols under different land uses

\begin{tabular}{lccccccc}
\hline \multicolumn{1}{c}{ Mineralogy (\%) } & $\begin{array}{c}\text { Depth } \\
\text { (cm) }\end{array}$ & Quartz & $\begin{array}{c}\text { Oxide/ } \\
\text { Iron } \\
\text { hydroxide }\end{array}$ & Opaque & Zircon & $\begin{array}{c}\text { Lytic } \\
\text { fragments }\end{array}$ & Ilmenite \\
\hline Undisturbed forests (UF) & $0-20$ & 88.11 & 10.67 & - & - & - & $<1$ \\
& $20-40$ & 80.55 & 18.24 & - & - & - & 1.82 \\
\hline Cattle ranching pastures & $0-20$ & 94.77 & 5.34 & - & TR & - & 1.67 \\
(CRP) & $20-40$ & 93.33 & 7.33 & - & - & - & 1.78 \\
\hline \multirow{2}{*}{ Mixed crops (MC) } & $0-20$ & 95.45 & 3.67 & - & TR & - & 2.11 \\
& $20-40$ & 95.67 & 7.00 & - & - & - & 2.00 \\
\hline
\end{tabular}

Source: Authors (2020) 
The particle size and mineralogical composition demonstrate how sensitive these environments are to changes in the landscape due to deforestation, and how unstable the maintenance of carbon stocks is due to such conditions. Sandy soils tend to present more pronounced carbon loss when compared to clayey ones. The lower aggregation may justify this among particles, higher leaching, and higher exposure of aggregates to oxidation (OLIVEIRA et al., 2015), which triggers fast erosive processes (BASTOS et al., 2014). Resulting in a negative cycle of events that disrupt the carbon stored in the soil and its emission.

\section{CONCLUSIONS}

There were no significant differences in soil carbon stocks between undisturbed forests and cattle ranching pastures. Soils under mixed crops (at age 10 years) presented lower carbon stocks (23.32\% lower than in undisturbed forests).

The layer $0-20 \mathrm{~cm}$ contains $69.31 \%, 67.91 \%$, and $71.33 \%$ of the carbon stored at the $0-40 \mathrm{~cm}$ in undisturbed forests, cattle ranching pastures, and mixed crops.

The land-use change from forested areas onto other land uses led to an increase in soil density.

The carbon fraction decreases as the soil depth increases, regardless of the land use.

Plinthosol, due to its textural and mineralogical characteristics, should be the focus of differentiated management practices that provide the maintenance of productive conditions after the replacement of the forest for other use systems.

Plinthosols are widely distributed across the Amazon. They constitute large environments occupied by human activities in the region. Understanding carbon stocks can guide the best ways to manage them and, thus, guide biodiversity conservation policies and avoid greenhouse gase missions that further aggravate climate change context. 


\section{ACKNOWLEDGMENTS}

The authors thank to Petrobras and National Bank for Economic and Social Development (BNDES) for supporting this research. This study was also supported by the Federal University of Rondônia and the Federal University of Paraná.

\section{REFERENCES}

ABRAMOVAY, R. Alimentos versus população: está ressurgindo o fantasma malthusiano? Ciência e Cultura, São Paulo, v. 62, n. 4, p. 38-42, 2010.

ALVARES, C. A. et al. Köppen's climate classification map for Brazil. Meteorologische Zeitschrift, Stuttgart, v. 22, n. 6, p. 711-728, 2013.

ARYAL, D. A. et al. Soil organic carbon depletion from forest to grassland conversion in Mexico: a review. Agriculture, Basel, v. 181, n. 8, p. 1-15, 2018.

BARROS, H. S.; FEARNSIDE, P. M. Soil carbon stock changes due to edge effects in central Amazon forest fragments. Forest Ecology and Management, Amsterdam, v. 379, p. 30-36, 2016.

BASTOS, A. S. et al. Physical environment aspects as subsidy to occupation in southwest Amazon conservation units - A case study relating to the Jamari National Forest and its surrounding areas. International Journal of Environment and Sustainability, Ottawa, v. 2, n. 2, p. 9-22, 2014.

BERNOUX, M. et al. Bulk densities in the Brazilian Amazon soils related to other soil properties. Soil Science Society of America Journal, Madison, v. 62, n. 3, p. 743-749, 1998.

BERNOUX, M.; ETCHEVERS, J.; CERRI, C. E. P. Carbon sequestration in soils of Latin America. New York: Haworth, 2006.

BROADBENT, E. N. et al. Forest fragmentation and edge effects from deforestation and selective logging in the Brazilian Amazon. Biological Conservation, Essex, v. 141, n. 7, p. 1745-1757, 2008

CERRI, C. C.; VOLKOFF, B.; ANDREAUX, F. Nature and behaviour of organic matter in soils under natural forest, and after deforestation, burning and cultivation, near Manaus. Forest Ecology and Management, Amsterdam, v. 38, p. 247-257, 1991.

CERRI, C. E. P. et al. Predicted soil organic carbon stocks and changes in the Brazilian Amazon between 2000 and 2030. Agriculture, Ecosystems and Environment, Amsterdam, v. 122, p. 58-72, 2007.

COSTA, O. V. et al. Soil carbon stocks under pasture in costal tableland areas in southern Bahia State, Brazil. Revista Brasileira de Ciência do Solo, São Paulo, v. 33, p. 1137-1145, 2009. 
DE JONG, B. et al. Greenhouse gas emission between 1993-2002 from land use change and forestry in Mexico. Forest Ecology and Management, Amsterdam, v. 260, p. 1689-1701, 2010.

DESJARDINS, T. et al. Effects of forest conversion to pasture on soil carbon content and dynamics in Brazilian Amazon. Agriculture, Ecosystems and Environment, Amsterdam, v. 103, p. 365-372, 2004.

DEXTER, A. R. Soil physical quality Part I. Theory, effects of soil texture, density, and organic matter, and effects on root growth. Geoderma, Amsterdam, v. 120, p. 201-214, 2004.

DOURADO, T. A.; SILVA, L. F. S.; MARINHO, M. A. Performance of a reciprocal shaker in mechanical dispersion of soil samples for particle-size analyses. Revista Brasileira de Ciências do Solo, São Paulo, v. 36, p. 1131-1148, 2012.

FEARNSIDE, P. M.; BARBOSA, R. I. Soil carbon changes from conversion of forest to pasture in Brazilian Amazon. Forest Ecology and Management, Amsterdam, v. 108, p. 147-166, 1998.

FOOD AND AGRICULTURE ORGANIZATION OF THE UNITED NATIONS. FAO statistical yearbook 2013 world food and agriculture. Rome, 2013.

FOOD AND AGRICULTURE ORGANIZATION OF THE UNITED NATIONS. Faostat: food and agriculture data. Rome, 2017. Disponível em: http://www.fao.org/faostat/en/\#data. Acesso em: 25 jan. 2019.

GAITÁN, L. et al. Climate-smart livestock systems: an assessment of carbon stocks and GHG emissions in Nicaragua. Plos One, [s. I.], v. 11, n. 12, e0167949, 2016.

GALLAGE, C. P. K.; UCHIMURA, T. Effects of dry density and grain size distribution on soil-water characteristic curves of sandy soils. Soils and Foundations, Tokyo, v. 50, n. 1, p. 161-172, 2010.

GARCIA, C. H. P. et al. Chemical properties and mineralogy of soils with plinthite and petroplinthite in Iranduba (AM), Brazil. Revista Brasileira de Ciência do Solo, Viçosa, MG, v. 37, n. 4, p. 936-946, 2013.

GATTO, A. et al. Carbon storage in the soils and in the biomass of eucalypt plantations. Revista Brasileira de Ciência do Solo, São Paulo, v. 34, p. 1069-1079, 2010.

INSTITUTO NACIONAL DE PESQUISAS ESPACIAIS (Brasil). Projeto PRODES de monitoramento da floresta amazônica brasileira por satélite. Taxas anuais 1988-2017. Brasília, 2018. Disponível em: http://www.obt.inpe.br/prodes/index.php. Acesso em: 10 dez. 2018.

INTERGOVERNMENTAL PANEL ON CLIMATE CHANGE. Climate change 2013: the physical science basis. In: CONTRIBUTION of working group 1 to the fifth assessment report of the intergovernmental panel on climate change. Cambridge: Cambridge University Press, 2013. Disponível em: http://www.ipcc.ch/report/ar5/wg1/. Acesso em: 20 jan. 2019.

KATO, E. et al. Physical properties and organic carbon of a Savannah Red-Yellow Latossol under different plant covers. Bioscience Journal, Uberlândia, v. 26, n. 5, p.732-738, 2010.

LENCI, L. H. V. et al. Phytosociological aspects and soil quality indicators in agroforestry systems. Nativa, Sinop, v. 6, p. 745-753, 2018. 
MAAS, G. C. B. et al. Combining sample designs to account for the whole necromass carbon stock in Brazilian Atlantic Forest. Journal of Sustainable Forestry, [s. 1.], v. 40, n. 1, p. 1-17, 2020. DOI: 10.1080/10549811.2020.1796710.

MARQUES, J. D. O. et al. Soil carbon stocks under Amazonian Forest: distribution in the soil fractions and vulnerability to emission. Open Journal of Forest, [s. I.], v. 7, p. 121-142, 2017.

OLIVEIRA, E. S.; REATTO, A.; ROIG, H. L. Soil carbon stocks according to landscape components. Cadernos de Ciência \& Tecnologia, Brasília, v. 32, n. 1/2, p. 71-93, 2015.

PIRES, F. R. M. Arcabouço geológico. In: CUNHA, S. B. C.; GUERRA, A. J. T. (org.). Geomorfologia do Brasil. 5. ed. Rio de Janeiro: Bertrand Brasil, 2009. p. 17-69.

PULROLNIK, K. Transformações do carbono no solo. Planaltina: Embrapa Cerrados, 2009. 36 p.

ROGELJ, J. et al. Paris Agreement climate proposals need a boost to keep warming well below $2{ }^{\circ} \mathrm{C}$. Nature, London, v. 534, p. 631-639, 2016.

RONQUIM, C. C. Conceitos de fertilidade do solo e manejo adequado para regiões tropicais. Campinas: Embrapa Monitoramento por Satélite, 2010. 26 p.

SAATH, K. C. O.; FACHINELLO, A. L. Crescimento da demanda mundial de alimentos e restrições do fator terra no Brasil. RESR, Piracicaba, v. 56, n. 2, p. 195-212, 2018.

SALIMON, C. I.; WADT, P. G. S.; MELO, A. W. F. Dinâmica de carbono na conversão de floresta para pastagens em Argissolos da formação geológica Solimões, no Sudoeste da Amazônia. Revista de Biologia e Ciências da Terra, [s. I.], v. 7, n. 1, p. 29-38, 2007.

SHAH, A. N. et al. Soil compaction effects on soil health and crop productivity: an overview. Environmental Science and Pollution Research, [s. I.], v. 24, n. 11, p. 10056-10067, 2017.

TRUMBORE, S.; CAMARGO, P. B. Dinâmica do carbono no solo. In: KELLER, M. et al. Amazonia and Global Change. [S. I.]: American Geophysical Union, 2009. v. 186. p. 451-462.

TUBIELLO, F. N. et al. The contribution of agriculture, forestry and other land use activities to global warming, 1990-2012. Global Change Biology, New Jersey, v. 21, p. 2655-2660, 2015.

\section{Authorship Contribution}

\section{1 - Alexis de Sousa Bastos}

Geographer, Dr.

https://orcid.org/0000-0003-0236-7554•alexis@rioterra.org.br

Contribution: Conceptualization, Formal Analysis, Funding acquisition, Methodology, Project administration, Writing - original draft 


\section{2 - Carlos Roberto Sanquetta}

Forestry Engineer, Dr.

https://orcid.org/0000-0001-6277-6371•sanquetta@ufpr.br

Contribution: Investigation, Methodology, Supervision, Validation, Writing - original draft

\section{3 - Vanderlei Maniesi}

Geologist, Dr.

https://orcid.org/0000-0003-0369-6069•maniesi@unir.br

Contribution: Investigation, Methodology, Supervision, Writing - original draft

\section{4 - Mateus Niroh Inoue Sanquetta}

Forestry Engineer

https://orcid.org/0000-0002-2633-5509•mateus.sanquetta@gmail.com

Contribution: Formal Analysis, Validation, Visualization, Writing - review \& editing

\section{5 - Ana Paula Dalla Corte}

Forestry Engineer, Dr.

https://orcid.org/0000-0001-8529-5554•anapaulacorte@gmail.com

Contribution: Validation, Writing - review \& editing

\section{How to quote this article}

Bastos, A. S.; Sanquetta, C.; Maniesi, V.; Sanquetta, M. N. I.; Corte, A. P. D. Amazon plinthosols: carbon stocks and physical properties under different land uses. Ciência Florestal, Santa Maria, v. 31, n. 2, p. 749-765, 2021. DOI 10.5902/1980509838211. Available from: https://doi. org/10.5902/1980509838211. Accessed: xx abbreviated-month 2021. 